\title{
O RACJONALNOŚCI TEORETYCZNEJ, PRAKTYCZNEJ I GLOBALNEJ W FILOZOFII ROBERTA AUDIEGO
}

Profesor Ryszard Kleszcz zrealizował kilka interesujących i bardzo ważnych projektów badawczych (nad niektórymi wciąż pracuje). Jeden z nich - bodaj największy - dotyczy natury racjonalności. Na ten temat filozof napisał wiele prac, w tym obszerną monografię $O$ racjonalności. Studium epistemologiczno-metodologiczne (1998). W książce tej analizuje pojęcie racjonalności oraz pojęcia jej pokrewne i przeciwne, dokonuje przeglądu najważniejszych typów (poziomów) racjonalności, szuka właściwych kryteriów dla racjonalności uniwersalnej. Dociekania swoje prowadzi w perspektywie filozoficznej. Uwaga dotycząca perspektywy jest istotna, ponieważ badania nad racjonalnością prowadzone są na szeroką skalę przynajmniej od kilku dekad w ramach tak różnych dziedzin i dyscyplin, jak: socjologia, politologia, ekonomia, psychologia, biologia ewolucyjna, neurobiologia czy teoria gier. Dodam jeszcze, że Kleszcz czyni to jako filozof zorientowany analitycznie, ale nie scjentystycznie. Przedmiotem jego badań - we wspomnianej rozprawie - jest racjonalność jako normatywna kategoria epistemologiczno-filozoficzna. Tak rozumianą racjonalność można potraktować jako pewien ogólny wariant idei regulatywnej, który obowiązywać ma wielu - jeśli nie wszystkich - w ramach aktywności poznawczej.

Wydaje się, że podział na racjonalność przekonań i racjonalność działań Kleszcz uważa nie tylko za najbardziej ogólny, ale i podstawowy:

Przyjrzenie się „z lotu ptaka” analizowanemu terminowi pozwala dostrzec, że używany on bywa współcześnie zwykle w dwu typach kontekstów [...]. Pierwszy, w którym mówić można o racjonalnych przekonaniach (beliefs) czy też racjonalnym myśleniu. W drugim kontekście chodzi o racjonalność działania (aktów) (Kleszcz 1998, s. 39).

Przekonania mogą dotyczyć sfery faktów, działania, dążeń czy też wartościowania. Czasami bywają przeciwstawiane niezawodnej wiedzy. 
Wówczas rozumiane są jako stany subiektywne, dopuszczające niepewność i możliwość błędu. Przekonania mogą być też odróżniane od sądów. $\mathrm{Z}$ takim podejściem sympatyzuje Kleszcz. Wówczas przekonania traktowane są jako nastawienia (którym nie można przypisać wartości prawdy lub fałszu) wobec sądów (którym można przypisać wartość logiczną):

W przypadku przekonań za pomocą zwrotów ‘myślę, że p', 'jestem przekonany, że p', ogólnie 'osobnik x jest przekonany, że p' wyraża się stosunek, w jakim dany osobnik ('podmiot przekonania') pozostaje do sądu w sensie logicznym. Aby mieć do czynienia z przekonaniem, dany sąd musi być rozumiany. Chodziłoby przy tym o zrozumienie treści danego sądu, co byłoby warunkiem podjęcia decyzji co do uznania (odrzucenia) tegoż sądu (Kleszcz 1998, s. 41).

Przekonania mogą być analizowane na różnych płaszczyznach. Kleszcz - przypomnijmy - zainteresowany jest przede wszystkim płaszczyzną epistemologiczną i metodologiczną. Zajmuje go:

kwestia zasadności akceptowania pewnych przekonań (ich treści). W tym kontekście odwołując się do terminu „racjonalność” powiedzieć można, że przekonania nie kwalifikowane prawdziwościowo mogą być charakteryzowane jako racjonalne lub nie czy też $\mathrm{w}$ innej konwencji terminologicznej słuszne lub nie (Kleszcz 1998, s. 42).

Samą racjonalność teoriopoznawczą Kleszcz rozumie dosyć szeroko, włączając w nią racjonalność ontologiczną. Dotyczy ona bowiem zarówno samej rzeczywistości, jak i jej poznania - treści poznania. Racjonalność teoriopoznawczą filozof traktuje jako cechę przypisywaną „treści myślowej, dostępnej poznaniu rozumowemu. Poznanie racjonalne wiąże się wtedy z takim jego ujęciem, w którym traktowane jest ono jako osiąganie prawdy, dotycząc treści intelektualnych, intersubiektywnie sprawdzalnych i komunikowalnych" (Kleszcz 1998, s. 60).

Kleszcz zainteresowany jest również racjonalnością praktyczną. Jest on zwolennikiem takiego modelu racjonalności praktycznej, w którym dąży się do umiejętnego łączenia racjonalności formalnej z racjonalnością rzeczową. Jego zdaniem racjonalność formalna akcentuje sposób i środki prowadzące do jakiegoś celu, ale pomija kwestię samych celów:

Działanie racjonalne $\mathrm{w}$ sensie formalnym to działanie skuteczne [...]. Określenie skuteczności działania wymaga odwołania się do pewnej przyjętej miary. Należy w tym przypadku wskazać najlepsze (optymalne) metody prowadzące do danego - przyjmowanego przez działającego - celu. Pozwala to na określenie nie tylko skuteczności danego działania (tego czy osiąga ono cel), lecz także jego dokładności w wykonaniu oraz ekonomiczności. Tę zaś rozumieć można jako wybór, nie tylko najskuteczniejszych, ale i najefektywniejszych (przy danej skuteczności) metod działania [...]. Wtedy, gdy wskazuje się 
na optymalne metody prowadzące do danego celu, to dla metod tych można ustalić rozkład prawdopodobieństwa stopnia realizacji zakładanego celu. Najogólniej mówiąc, skuteczność utożsamiać można z częstością, z jaką dana metoda prowadzi do osiągnięcia przyjętego celu (Kleszcz 2007b, s. 113-114).

Natomiast racjonalność rzeczowa koncentruje się na ocenie samego celu. Ewaluacja celu może być determinowana przez kulturę - cel będzie racjonalny, jeśli będzie zgodny ze standardami danej kultury. Może być też kształtowana niezależnie od kultury. Racjonalność celów można ocenić w kontekście życia człowieka: jako izolowanego indywiduum i jako indywiduum żyjącego w jakiejś wspólnocie (por. Kleszcz 2007b, s. 122-128).

W ogólności Kleszcz wyróżnił i zanalizował siedem typów racjonalności:

1) racjonalność pojęciową;

2) racjonalność logiczną;

3) racjonalność ontologiczną;

4) racjonalność teoriopoznawczą;

5) racjonalność metodologiczna;

6) racjonalność praktyczną i

7) racjonalność aksjologiczną (por. Kleszcz 1998, s. 38-85)ํ․

Kleszcz bada poszczególne typy racjonalności, ale pyta też o racjonalność uniwersalną. To jest zresztą główny przedmiot jego rozprawy $\mathrm{O}$ racjonalności. Jest to „problem podstaw, na których się opierając akceptować można dane przekonania" (Kleszcz 1998, s. 106). W punkcie wyjścia filozof odnotowuje: „Wiele z dotychczasowych prób scharakteryzowania racjonalności sprowadza się do podania jej warunków (kryteriów). Spełnienie tychże kryteriów traktuje się przy tym, jako warunek konieczny lub wystarczający racjonalności" (Kleszcz 1998, s. 104). I dalej podąża tym

${ }^{1}$ Wcześniej siedem pojęć racjonalności wyróżnił Mario Bunge: 1) pojęciową (dążenie do jasności), 2) logiczną (dążenie do spójności), 3) metodologiczną (domaganie się uzasadnienia), 4) epistemologiczną (dbanie o empiryczne wsparcie), 5) ontologiczną: przyjęcie spójnego światopoglądu zgodnego ze współczesną nauką i technologia, 6) teleologiczno-ewaluacyjną (valuational) (dążenie do celów, które, prócz tego, że są osiągalne, są warte osiągnięcia), 7) praktyczną (dobieranie środków, które mogą pomóc w osiągnięciu tych celów). Te pojęcia racjonalności nie są wzajemnie niezależne, ale powiązane są relacją presupozycji i tworzą system - zbiór częściowo uporządkowany: racjonalność logiczna zakłada racjonalność metodologiczna, racjonalność epistemologiczna zakłada racjonalność metodologiczną itd. (por. Bunge 1987, s. 5-15). Na wielość różnych ujęć racjonalności wskazują wciąż żywe debaty, które koncentrują się na kilku dychotomiach: 1) racjonalność normatywna - racjonalność deskryptywna, 2) racjonalność instrumentalna - racjonalność nieinstrumentalna, 3) racjonalność kartezjańska - racjonalność niekartezjańska, 4) racjonalność jawna - racjonalność niejawna, 5) racjonalność oparta na wyjaśnieniu - racjonalność oparta na interpretacji, 6) racjonalność zamierzona i racjonalność niezamierzona (por. Bronner, Di Iorio 2018, s. 1-6). 
tropem. Najpierw analizuje i poddaje krytyce tzw. standardowy model racjonalności, który za najważniejsze kryteria obiera: 1) postulat należytej artykulacji, 2) respektowanie wymogów logiki, 3) należyte uzasadnienie. A następnie prezentuje własny, tzw. dwupiętrowy model racjonalności. Pierwszy poziom obejmuje pewne ogólne i uniwersalne zasady („,metazasady"). Są to: 1) ścisłość językowa, 2) przestrzeganie zasad logiki, 3) krytycyzm, 4) rozwiązywalność problemu. Drugi zaś - szczegółowe typy poznania i odpowiednie dla nich racjonalności (por. Kleszcz 1998, s. 112113). Zarówno eneza i struktura, jak i samo pojęcie racjonalności, jak dalej pokażę, mogą mieć nieco inną wykładnię.

\section{Racjonalność teoretyczna, racjonalność praktyczna, racjonalność globalna}

W eseju tym pochylę się nad modelem racjonalności globalnej (ogólnej), a dokładniej zunifikowanej, na którą składają się racjonalność teoretyczna i racjonalność praktyczna (odmiennie interpretowane niż w ujęciu Kleszcza). Powstało imponująco wiele prac dotyczących racjonalności teoretycznej, nieco mniej na temat racjonalności praktycznej - zarówno rzeczywistości moralnej, jak i pozamoralnej. Natomiast niewiele jest takich opracowań, które szczegółowo objaśniaja, czym są obie racjonalności, jak się mają do siebie, a ponad to takich, które podejmowałyby próbę połączenia obu w jedną racjonalność globalną. Wielu autorów uważa, że pełna teoria racjonalności jest poza naszym zasięgiem. Nieliczni myślą inaczej, maksymalistycznie, i podejmują się - z różnym rezultatem - wypracowania takiej syntetycznej teorii. Do tych ostatnich należy Robert Audi, którego propozycję zaprezentuję poniżej. Uważam, że jest to próba nader ciekawa i ważna, choć momentami zbyt szczegółowa, zawiła i przez to niejasna. Racjonalność jest dla Audiego - najprościej rzecz ujmując - rodzajem responsywności na racje i podstawy. Racjonalność to, mówiąc nieco inaczej, sposób funkcjonowania w świecie oparty na przekonaniach i pragnieniach, w którym przekonanie jest odpowiedzią na świat, którego doświadczamy, a działanie jest próbą nakłonienia świata do zmiany (por. Audi 2001, s. 61).

W swoich rozważaniach Audi wychodzi od przywołania pewnego doświadczenia. Jego zdaniem bowiem fundamentem poznawania i działania jest doświadczenie - wewnętrzne przeżycie czegoś. Filozof wskazuje na doświadczenie estetyczne w czasie koncertu fortepianowego. Samo wysłuchanie np. sonaty f-moll Appassionata może dostarczyć nie tylko wielu przepięknych wrażeń słuchowych, ale także wzrokowych. Jeżeli tak się 
stanie, doświadczenie to będzie źródłem przekonań (i wiedzy) na temat wykonanego koncertu. Będzie też stanowić przyczynę pragnienia i powód do działania: ta rzadka integracja melodii, harmonii i wzrostu dynamiki dźwięku dostarcza powodu nie tylko do dalszego słuchania, uczestniczenia $\mathrm{w}$ podobnych koncertach, ale też np. wydania pochlebnej recenzji czy sformułowania zachęty dla innych do słuchania tego wykonawcy. Doświadczenie zatem jest źródłem przekonań i pragnień, a co za tym idzie, także racjonalności teoretycznej (poznawczej) i racjonalności praktycznej. "Nieprzypadkowo rozpoczynam - pisze Audi - od doświadczenia, które jest jednocześnie percepcyjne i nagradzające. Jestem zainteresowany tym, w jaki sposób doświadczenie jest połączone z racją" (2001, s. 4).

\section{Podstawowe źródła i sposoby uzasadnienia wiedzy}

Audi jest reprezentantem pewnej formy fundacjonistycznej teorii racjonalności, która jest rezultatem przyjętego przez filozofa fundacjonizmu teoriopoznawczego i fundacjonizmu motywacyjnego. Jak wiadomo, w ogólności fundacjonalizm głosi, że na gmach naszej wiedzy składają się przynajmniej dwa poziomy: podstawowy i nadbudowana na nim warstwa wyższa. Poziom bazowy tworzą podstawowe przekonania, uzasadniane bezpośrednio, część drugą zaś - przekonania pochodne uzasadniane inferencyjnie. Często posługiwano się w tym kontekście metaforą piramidy. Metafora ta ma swoje zalety i wady. Jednak zdaniem Audiego ma więcej wad - przede wszystkim wcale nie pomaga w zrozumieniu architektury wiedzy. Pod względem kształtu, złożoności, łączności, treści i siły, fundamenty i nadbudówka nie tworzą stałej struktury i mogą się zmieniać w nieskończoność. Lepiej jest według Audiego sięgnąć po figurę drzewa, które:

może rozwinąć nowe korzenie $\mathrm{w}$ dowolnym momencie i w dowolnym kierunku; stare korzenie mogą rosnąć lub, w niektórych przypadkach, usychać; system korzeniowy może być więcej niż wystarczający do obsługi reszty drzewa, ale może być też do tego zadania nieodpowiedni [...]. Architektura przyrody jest znacznie lepszym modelem intelektu niż geometrycznie sztuczna odwrócona piramida (Audi 2001, s. 40).

Przekonania podstawowe zdaniem filozofa powstają dzięki doświadczeniu, które ma charakter przyczynowy, np. nasze dane percepcyjne są powodowane rzeczywistymi obiektami i zdarzeniami. Problem ten wiąże się z samymi podstawami poznania, tj. źródłami poznania. Zapytajmy zatem najpierw: czym są źródła wiedzy w ogóle? Czym są podstawowe źródła wiedzy? 
Źródło wiedzy jest wedle Audiego czymś takim w życiu poznającego podmiotu, co wytwarza przekonania (racjonalne przekonania), ustanawiając tym samym wiedzę. Ale jest też czymś więcej. Określić źródło wiedzy to nie tylko wskazać, skąd ona się bierze, ale również określić jej podstawy. Podstawy są tym, na mocy czego ktoś coś wie lub jest zasadnie przekonany o czymś (por. Audi 2002, s. 83). Uznać coś za źródło wiedzy podstawowej to uznać, że wytwarza ono wiedzę bez pozytywnej zależności - zależności od działania innego źródła wiedzy i uzasadnienia. Nazwać jakieś źródło podstawowym to tyle, co przyznać mu epistemiczną niezależność (por. Audi 2002, s. 78). Kiedy zaś w poznawaniu dodatkowo korzystamy jeszcze z jakiegoś innego źródła, np. z czyjegoś świadectwa lub z istniejącej już wiedzy (pojęć i przekonań zawartych w pamięci), wówczas, zdaniem Audiego, mamy do czynienia z pochodnym źródłem wiedzy. Wedle filozofa do klasycznych źródeł należą: 1) percepcja (perception), 2) pamięć (memory), 3) świadomość introspekcyjna (consciousness) i 4) rozum lub intuicja intelektualna (reason). Poniżej krótka charakterystyka każdego z nich (por. Audi 2001, s. 13-20; 2002, s. 71-78).

Percepcja to zdolność podmiotu poznającego do postrzegania obiektów w świecie za pomocą zmysłów. Tak ogólnie rozumiana percepcja nie jest dla Audiego pojęciem zamkniętym. Mogą bowiem pojawić się dotąd nieznane rodzaje reakcji percepcyjnej, np. na nowe lub niezwykłe rodzaje obiektów lub zdarzeń. Wówczas można poszerzyć bądź zmodyfikować pole znaczeniowe tego pojęcia. Należy też pamiętać, że nauki zajmujące się działaniem percepcji, jak psychologia poznawcza, kognitywistyka czy neurobiologia, wciąż odkrywają nowe aspekty procesów percepcyjnych, które rzeczywiście powinny być uwzględnione $\mathrm{w}$ analizie pojęcia percepcji.

Pamięć to zdolność podmiotu poznającego do przypominania (remember), a także przywoływania (recalling), które pociąga za sobą przypominanie, choć z niego nie wynika, wspominanie (recollecting). To zaś jest podobne do przywoływania, lecz z reguły implikuje tylko pewien epizod przywoływania, pewną sekwencję lub zbiór detali. Pamięć jest źródłem wiedzy (przekonań pamięciowych) i uzasadnienia.

Świadomość introspekcyjna to zdolność podmiotu poznającego do wglądu i poznania własnych stanów mentalnych oraz treści własnych (aktualnych) przeżyć psychicznych. Dostarcza nam ona bezpośredniej, nieinferencyjnej wiedzy na temat naszego świata wewnętrznego. Umożliwia dostęp do szerokiej dziedziny bytów mentalnych: doznań, myśli, wyobrażeń, przedmiotów abstrakcyjnych, takich jak liczby i pojęcia. Nie jest lub raczej nie musi być - jak niektórzy utrzymywali - niepowątpiewalnym źródłem wiedzy. 
Rozum to zdolność podmiotu poznającego do takich czynności intelektualnych, jak: refleksja (reflection), rozumowanie (reasoning), rozumienie (understanding), intuicja (intuition): rozmyślamy nad naturą jakiegoś problemu, rozumujemy $\mathrm{z}$ jakiejś przesłanki, rozumiemy jakieś pojęcie, nazwę lub zdanie, mamy wgląd w pewne prawdy. Są to jedynie wybrane przykłady. Lista tych czynności nie jest wyczerpująca, a one same nie są zupełnie niezależne, lecz nakładają się na siebie.

Przynajmniej trzy z omówionych źródeł - percepcja, świadomość introspekcyjna i intuicja intelektualna - należą do podstawowych źródeł wiedzy, ponieważ - jak wyżej - w swojej podstawowej i historycznie pierwotnej formie nie zależą pozytywnie od innych źródeł. Są autonomiczne. Wszystkie one mogą wytwarzać przekonania o nieinferencyjnym charakterze, jako że nie są oparte na innych przekonaniach. Oczywiście ich autonomia w pewnym momencie może zostać zburzona. Nawet percepcja może zależeć np. od pojęć i przekonań $\mathrm{w}$ pamięci. Zależność percepcji od czynników różnych od doświadczenia zmysłowego jest jednakże tym, co Audi nazywa zależnością negatywną. Nie pokazuje ona tego, że percepcja nie jest źródłem wiedzy, ale tylko to, że w pewnych sytuacjach źródło to może być w pewien sposób uzupełnione lub zablokowane. Takie proste logiczne prawdy, jak te $w$ formie , ,jeżeli wszystkie A są B i wszystkie B są C, to wszystkie A są C", mogą być znane po prostu na podstawie odpowiedniego ich zrozumienia. W tym sensie intuicja intelektualna jest niezależnym źródłem poznania. Pamięć budzi pod tym względem najwięcej wątpliwości. Audi jest skłonny nawet przyznać, że nie jest ona podstawowym źródłem wiedzy. Jeżeli pamiętamy coś i przez to wiemy coś, musieliśmy do tego dojść i poznać to poprzez np. percepcję lub rozumowanie. Pamięć jest na pewno jednak - jak stwierdza - epistemicznie istotnym źródłem (essential source). Wszystko to, o czym myślimy jako o naszej wiedzy pojęciowej, zdobywanej w wyniku doświadczenia i uczenia się, zawaliłoby się, gdyby pamięć tego wszystkiego nie podtrzymywała. Rozum i świadomość introspekcyjna są nie tylko podstawowymi, ale także wyjątkowymi źródłami. Ważnym źródłem wiedzy jest też świadectwo, ale nie należy ono do standardowych źródeł podstawowych.

Gwarantem racjonalności jest uzasadnienie. W związku z uzasadnieniem istnieje wiele mniej lub bardziej szczegółowych pytań. Jakie są źródła uzasadnionych przekonań? W jaki sposób takie przekonania są gruntowane? W jaki sposób ich uzasadnienie różni się w zależności od kontekstu? W jaki sposób ich uzasadnienie może zostać przezwyciężone np. dzięki zaprzeczającym im dowodom? Jaka jest rola koherencji lub niekoherencji w tym gruntowaniu lub przezwyciężaniu? W jaki sposób inne przekonania mogą być uzasadnione na podstawie przekonań już uzasadnionych? Na te i kilka innych pytań Audi udziela obszernych i jak się wydaje, wyczerpujących odpowiedzi. Tutaj ograniczę się tylko do kilku konstatacji. 
Uzasadnienie prowadzi do racjonalnych przekonań. Podstawowymi źródłami uzasadnienia są te, które uzasadniają wiedzę bez pozytywnej zależności od działania innego źródła uzasadnienia. W ten sposób uzasadniają cztery wspomniane podstawowe źródła. Mogą wytworzyć one przekonania, które są nieinferencyjnie uzasadnione, gdyż ich uzasadnienie nie jest wywiedzione $\mathrm{z}$ innych przekonań.

Podstawowe źródła wiedzy i uzasadnienia dostarczają nam racjonalnych przekonań, ale nie są niezawodne, co więcej, mogą prowadzić do wiedzy, która może być błędna i w związku z tym podlegać korekcie. Wynika to $\mathrm{z}$ tego, że ich działanie nie jest doskonałe. Percepcja podatna jest na złudzenia i pochopną interpretację danych wrażeniowych. Dane introspekcyjne nie są niepowątpiewalne. Nawet rozum nie jest nieomylnym źródłem uzasadnienia wiedzy (i racjonalności). Uzasadnienie jest zawodne i stanowi uzasadnienie li tylko prima facie. Jednak źródła te, zdaniem Audiego, tworzą najbardziej pierwotną podstawę - nie mogą być uzasadnione przez coś bardziej podstawowego.

Audi uwzględnia $w$ swoich analizach również rolę koherencji i niekoherencji w uzasadnianiu i dla racjonalności. Koherencja to wewnętrzna spójność w pewnym zbiorze przekonań lub zdań. Ale - podkreśla też filozof - pozytywna koherencja powinna być rozumiana jako coś daleko więcej niż tylko wzajemna spójność, choć - jednocześnie - nie tak daleko, żeby można ją było uznać za wzajemne wynikanie. Jego zdaniem gdziekolwiek koherencja jest wprowadzana jako źródło uzasadnienia, tam musi działać jedno lub więcej spośród czterech źródeł podstawowych. Już proces percepcji generuje wiele przekonań, które zwykle są spójne. Te z kolei mogą być uzupełnione o przekonania z innego źródła. Wszystkie jednak powinny być spójne ${ }^{2}$. Źródła podstawowe wytwarzają nie tylko wiedzę i uzasadnione przekonanie, ale także koherencję. Koherencja nie tworzy uzasadnienia, ale do pewnego stopnia współtworzy i tym samym wzmacnia racjonalność. Niekoherencja natomiast, której wzorcem jest ewidentna logiczna niespójność, może uzasadnienie zniweczyć i tym samym osłabić racjonalnośćs ${ }^{3}$.

${ }^{2}$ Audi przyjmuje też koherencję konceptualną. Otóż nie można mieć przekonań, nie mając pojęć (które przychodzą i działają w rodzinach). Przyjmujemy pewne przekonania, ponieważ rozumiemy pojęcia, które konstytuują te przekonania. Czego nie możemy zrozumieć, o tym nie możemy też być przekonani. Koherencja konceptualna wyjaśnia kwestię nabywania pojęć i ich działania w sądach, inferencji, teoriach i dyskursach, por. (Audi 2002, s. 24-28).

${ }^{3}$ Warto podkreślić, że Audi szuka nie tylko tego, co wytwarza racjonalność, ale również tego, co ją unieważnia. Pokazuje, w jaki sposób kwestie te są ze sobą powiązane. Do czynników unieważniających, które mogą podważyć hipotetyczne uzasadnienie lub hipotetyczną wiedzę, należy wspomniana właśnie niekoherencja. 
Omówiłem podstawowe źródła wiedzy, które gruntują racjonalność podstawowych przekonań (i wiedzy). Racjonalności teoretycznej nie uzyskuje się jednak wyłącznie poprzez zdobywanie odpowiednio ugruntowanych przekonań w jednym, a nawet wszystkich źródłach podstawowych - przekonań bezpośrednich, nieinferencyjnych. Dla racjonalności teoretycznej istotne jest uzasadnienie inferencyjne.

Przekonanie może wynikać $\mathrm{z}$ doświadczenia lub z innych przekonań. Zgodnie z koncepcją Audiego, aby pewne przekonanie mogło stanowić rację uzasadniającą dla innego, samo musi być uzasadnione. Tylko dla niektórych przekonań racją uzasadniającą mogą być przekonanie bazowe, uzasadnione nieinferencyjnie. Inne mają charakter inferencyjny. W przechodzeniu od jednych przekonań do innych korzystamy z zasad transmisji. Zasady te określają warunki przekazania uzasadnienia z jednych przekonań na inne. Wszystkie one bazują na dwóch typach rozumowań: dedukcji i indukcji.

\section{Zasada transmisji uzasadnienia dotycząca dedukcji:}

Jeśli (a) pewien podmiot $S$ ma uzasadnione przekonanie, że $q$, (b) $q$ pociąga za sobą $p$, (c) związek ten jest przez $S$ rozumiany, (d) $S$ ma przekonanie, że $p$ na bazie przekonania, że $q$, to $S$ ma w pewnym stopniu uzasadnione przekonanie, że $p^{4}$.

\section{Zasada transmisji uzasadnienia dotycząca indukcji:}

Jeśli (a) pewien podmiot $S$ ma uzasadnione przekonanie, że $q$, (b) $q$ indukcyjnie wspiera $p$, (c) $S$ rozumie relację wspierania, (d) $S$ ma przekonanie, że $p$ na bazie przekonania, że $q$, to $S$ ma w pewnym stopniu uzasadnione przekonanie, że $p^{5}$.

A zatem jeżeli jakieś dwa przekonania - uzasadniające i uzasadniane - połączone są jedną z dwóch relacji - dedukcyjną lub indukcyjną w sposób bezbłędny (czyli pozbawiony błędów materialnych i formalnych) - to drugie możemy uznać za uzasadnione. Nie ma ograniczenia długości łańcucha inferencji. Można wyciągać wnioski z wniosków, a z nich kolejne wnioski itd. Istotne jest to, że dokonujemy rozumowań, o ile wymaga tego sytuacja.

4 "If (a) one justifiedly believes a proposition, q, (b) q entails p, (c) this entailment is within the scope of one's understanding, and (d) one believes $p$ on the basis of $q$, then one has some degree of justification for believing p" (Audi 2001, s. 43-44).

5 "If (a) one justifiedly believes a proposition, $q$, (b) $q$ inductively supports $p$, (c) this support relation is within the scope of one's understanding, and (d) one believes $p$ on the basis of $q$, then one believes $p$ with some degree of justification" (Audi 2001, s. 44). 


\section{Podstawowe źródła praktycznej racjonalności}

Racjonalne działanie opiera się na pewnych elementach motywujących, przede wszystkim na pragnieniu - w szerokim sensie tego słowa. Praktyczna racjonalność przybiera u Audiego pewną wersję motywacyjnego fundacjonizmu. A to znaczy, że nie wszystkie pragnienia mają ten sam status, nie wszystkie są podstawowe i równoważne. Motywacyjny fundacjonizm zakłada też współudział innych czynników, które uczestniczą w motywowaniu do działania. Audi nie pomija w swoich analizach intencji, środków i celów. Mniej więcej w tym samym czasie można mieć różne pragnienia. Jedne mogą powstawać pod wpływem bodźca, inne mogą być wydobyte z pamięci. Same pragnienia nie muszą jednak skutkować działaniem. Działania podejmujemy pod wpływem intencji. Nasze intencje nie są jednak prostymi bytami. Stanowią wypadkową innych elementów: pragnień, przekonań, celów czy ocen. Upraszczając nieco, można powiedzieć, że pod wpływem świadomego celu nasze pragnienia przekształcają się w wyraźną intencję, a następnie - pod wpływem odpowiednio dobranych środków - w plan działania. Nie będę zajmować się wszystkimi kategoriami, skoncentruję się jedynie na pragnieniach.

W swoich rozważaniach Audi wychodzi od podstawowych (wybra-

180 nych) analogii między racjami i racjonalnością teoretyczną a racjami i racjonalnością praktyczną.

Pierwsza analogia - ogólna - to analogia pomiędzy działaniem a przekonaniem. Dziedzinę racjonalności teoretycznej stanowi poznanie/ wiedza. Uzasadnione przekonania są ostatecznie ugruntowane w bardziej podstawowych elementach empirycznych lub intuicyjnych, takich jak percepcja lub rozumienie. Elementy te konstytuują podstawy przekonań. Natomiast dziedziną racjonalności praktycznej jest działanie. Również działanie racjonalne bazuje na czymś innym niż ono samo, a mianowicie na elementach motywujących, a przede wszystkim na pragnieniu. Ponadto, wedle Audiego, działanie opiera się na motywacji w bardzo podobny sposób, w jaki przekonania inferencyjne bazują na innych przekonaniach „przesłankowych”. Podobnie jak przekonania i wiedza, pragnienia i działanie mogą być racjonalne lub irracjonalne.

Druga podstawowa analogia, którą analizuje Audi, nie dotyczy przekonań i poznawania oraz działania w ogólności, ale przekonań opartych na innych, które wyrażają dla nich racje wspierające (przekonań inferencyjnych), oraz działań opartych na elementach motywacyjnych, które wyrażają dla nich takie racje (działań intencjonalnych). Tak jak istnieją przekonania bezpośrednie, proste i nieinferencyjne, tak na płaszczyźnie działania istnieją wewnętrzne (intrinsic) chcenia - chcenia rzeczy ze względu na same te rzeczy, a nie jako środki dla czegoś innego. Wewnętrzne 
chcenia nie bazują na innych chceniach - są pierwotne. Mamy pragnienie jedzenia i picia, spokoju i bezpieczeństwa, rozmowy i refleksji - które nie zależą w żaden sposób od innych, bardziej podstawowych.

Istnieje więcej podobieństw pomiędzy domeną poznania i działania (por. Audi 2001, s. 62-68). Mimo to są też wyraźne różnice. Poznawanie rodzi przekonania, którym przypisujemy wartość prawdy lub fałszu. Elementy motywujące, takie jak pragnienia czy intencje, które stanowią podłoże różnych działań, jak też same działania nie są ani prawdziwe, ani fałszywe. Poza tym elementy praktyczne wydają się subiektywne i relatywne, inaczej niż przekonania i wiedza. Choć i te ostatnie nie mają charakteru bezwzględnego obowiązywania ${ }^{6}$. Kiedy natomiast bliżej przyjrzymy się przekonaniom i pragnieniom, można zauważyć brak symetrii między nimi. Posiadanie jakiegoś pragnienia zwykle nie stanowi jeszcze wystarczającej racji do działania. Dopiero wraz z przekonaniem może ono motywować do działania. Natomiast przekonanie jest dużo bardziej samowystarczalne - nie zależy od pragnienia w takim stopniu, jak pragnienie od przekonania. Samo stanowić może rację dla wiedzy lub pewnych postaw. Przekonania aksjologiczne same z siebie mogą mobilizować do działania lub skłaniać do zaniechania pewnych działań.

Przechodzę obecnie do krótkiego omówienia natury i hierarchii pragnień. Czy mogą istnieć racjonalne wewnętrzne („podstawowe”) pragnienia, tak jak - na płaszczyźnie teoretycznej - istnieją racjonalne nieinferencyjne (i w tym sensie podstawowe) przekonania? Zdaniem Audiego - tak. Audi charakteryzuje pragnienie poprzez jego rolę motywującą do działania. Przy czym w punkcie wyjścia filozof czyni kilka rozróżnień. Przede wszystkim odróżnia: pragnienia wewnętrzne (intrinsic desires), pragnienia podstawowe (elemental desires) i pragnienia instrumentalne (instrumental desires).

Czym są pragnienia wewnętrzne? Audi odpowiada następująco:

Nie są one łatwe do zrozumienia i pewne naturalne nieporozumienia odnośnie do tego tematu pozwalają na ich upodobnienie do pragnień instrumentalnych lub pragnień jedynie nieinstrumentalnych, takich jak pragnienie odszukania kombinerek, gdy zapomina się, po co są one w ogóle potrzebne. Pragnienie, które nie jest jedynie nieinstrumentalne, nie jest tym samym, co wewnętrzne; a pragnienie wewnętrzne nie jest specjalnym rodzajem pragnienia instrumentalnego (Audi 2001, s. 81-82).

${ }^{6}$ Kwestię tego, czy istnieje jakiś rodzaj relatywizmu wbudowany w pojęcie racjonalności, Audi rozważa w rozdziale 7, (por. Audi 2001, s. 171-194). Skoro racjonalność jest ugruntowana na doświadczeniu, a doświadczenie przedstawicieli różnych kultur jest różne, to pojęcie racjonalności musi być zrelatywizowane kulturowo. Być może relatywizm ten jest nawet głębszy. Wszak zakres teoretycznej racjonalności dla każdego jest inny: każdy z nas ma odmienne doświadczenia i do innych aspektów doświadczenia przywiązuje wagę, ma inne możliwości poznawczo-logiczne i różne cele. 
Pragnienia wewnętrzne to według niego pragnienia najbardziej pierwotne, do pewnego stopnia fizjologiczne. To różne formy „przyjemności”, uciechy, zadowolenia czy radości, jakie towarzyszą nam w stosunkowo zwykłych sytuacjach życiowych; to, co przeżywamy, gdy wychodzimy na słońce po chłodnych dniach, lub to, co przeżywamy, gdy pływamy, słuchamy koncertu lub prowadzimy ciekawą rozmowę, o ile pojawiają się i są przeżywane same dla siebie. Te wewnętrzne pragnienia różnią się znacznie od instrumentalnych, które służą pewnym celom, np. wtedy, gdy ktoś jest przekonany, że za pomocą realizacji swoich pragnień osiągnie precyzyjnie wyznaczony sukces życiowy. Pragnienia pływania lub biegania dla zachowania dobrej kondycji zdrowotnej to zdecydowanie pragnienia instrumentalne. Inaczej niż pragnienie pływania dla samego pływania, pragnienie bycia na słońcu dla samego bycia - to pragnienie wewnętrze. Pragnienia wewnętrzne są wedle Audiego w pewnym sensie racjonalne. Ich racjonalność opiera się na pewnego rodzaju doświadczeniowych jakościach, trudnych do wyrażenia w języku, które stanowią podstawę innych pragnień ${ }^{7}$.

Pragnienia podstawowe natomiast to szczególny rodzaj tych pierwszych, odnoszą się one do odczuć przyjemności i bólu. Przyjemność i ból są ze sobą ściśle powiązane, są początkiem zarówno pragnienia, jak i awersji

182 i stanowią ważny czynnik motywujący. Odrębną sprawą jest to, czy ból i przyjemność są fundamentalnymi źródłami racji praktycznych, jak chcą tego hedoniści. Teoria Audiego - wbrew instrumentalistom - przyjmuje, że pragnienia podstawowe, najważniejsze motywatory działania, moga być racjonalne. Są one racjonalne, ponieważ ich spełnienie jest konieczne do realizacji innych pragnień.

Z jakościowej podstawy wewnętrznych pragnień można zdaniem $\mathrm{Au}-$ diego wyprowadzić nie tylko pragnienia egoistyczne, ale też altruistyczne. Doznajemy przyjemnych przeżyć, lecz spotykamy też innych ludzi, którzy mają podobne do naszych dyspozycje i podobne do naszych przeżycia. Wedle Audiego całkiem racjonalne i naturalne dla nas są empatia i altruistyczne pragnienia (por. Audi 2001, s. 141). A skoro tak, to racjonalność

7 Ciekawą analizę pojęcia pragnienia można znaleźć w pracy Neila Sinhababu Humean Nature. How Desire Explains Action, Thought, and Feeling (2017). Autor wyróżnia pięć podstawowych własności pragnienia. Po pierwsze, pragnienie motywuje działanie, kiedy jest połączone z przekonaniem na temat tego, w jaki sposób zwiększyć prawdopodobieństwo zaspokojenia tego pragnienia. Po drugie, wywołuje przyjemność i nieprzyjemność, kiedy mamy zmieniające się przekonania albo obrazowe reprezentacje dotyczące jego zaspokojenia. Po trzecie, kieruje uwagę na rzeczy, które wiążemy z jego przedmiotem. Po czwarte, wszystkie te efekty są wzmacniane, kiedy mamy obrazowe reprezentacje, które wiążemy z jego przedmiotem. Po piąte, pragnienia samoistne nie zmieniają się pod wpływem rozumowania, por. (Sinhababu 2017, s. 22-44). Warto też zapoznać się z trzema interpretacjami pragnienia T. Schroedera w Three Faces of Desire (2004). 
praktyczna zakłada pewne moralne standardy. Filozof podaje trzy podstawowe i wszechobecne zasady moralne:

1) powstrzymywać się od zabijania i zadawania cierpienia;

2) równo traktować wszystkich: sprawiedliwie nagradzać i karać;

3) troszczyć się o innych: przyczyniać się do większego zadowolenia i przyjemności innych (por. Audi 2001, s. 157).

Audi pyta też o to, jaki jest zakres racjonalności teoretycznej w kwestii praktycznego działania. Dla racjonalnego działania istotne są nie tylko doświadczenie i pragnienia, ale także przekonania. Same pragnienia nie wystarczają do tego, żeby działać racjonalnie. Może pojawić się w nas takie czy inne pragnienie, ale bez świadomości, że jest w nas to pragnienie, że warto je pielęgnować, że jego przedmiot jest możliwy (i w jaki sposób), samo pragnienie nie może aktywować działania i nim kierować. $W$ pewnym sensie pragnienie bez przekonania jest ślepe. I nawet jeśli stanowi rację dla działania, nie odgrywa swojej podstawowej motywacyjnej roli całkowicie samo. Ważne, a nawet kluczowe są przekonania.

\section{Racjonalność globalna}

Istnieją dwie podstawowe formy racjonalności: racjonalność teoretyczna i racjonalność praktyczna. Jeżeli dysponujemy już wyjaśnieniem obydwu tych form racjonalności, to posiadamy również solidną wiedzę potrzebną do zrozumienia tego, kim są racjonalne osoby w ogóle.

Wedle Audiego nie ma czystej i absolutnej racjonalności globalnej. Istnieją natomiast pewne podstawy i warunki, które sprzyjają tej racjonalności. Podstawę racjonalności człowieka tworzy doświadczenie. Składa się ono z elementarnych doznań, ale nie tylko. Doświadczenie łączy w sobie wrażliwość i reakcyjność. Bodźce prowokują nas do różnych reakcji, a reakcje te są $\mathrm{w}$ dużej mierze automatyczne i $\mathrm{w}$ pewnym sensie nagradzające - wtedy np., gdy podziwiamy malownicze widoki lub gdy słyszymy piękną muzykę. Doświadczenie to dostarcza racji - racji normatywnych - zarówno dla sfery teoretycznej, jak i praktycznej. Jest ono fundamentem racjonalnych przekonań i racjonalnych pragnień. Ludzka racjonalność według Audiego łączy się ściśle z pierwotnym doświadczeniem i uzasadnieniem: uzasadnieniem bezpośrednim, kiedy wynika ono z doświadczenia, i pośrednim, gdy za podstawę ma inne przekonania i pragnienia.

Warto jednak od razu za Audim podkreślić, że racjonalność jest zakresowo szerszym pojęciem niż uzasadnienie. Uzasadnienie sprzyja racjonalności, ale nie jest jej warunkiem koniecznym. Po pierwsze, jak zauważa filozof, nieuzasadnione przekonanie nie musi być irracjonalne, może 
wynikać z jakiegoś błędu w rozumowaniu. Po drugie, racjonalne przekonanie nie musi być racjonalne, nawet jeżeli dana osoba potrafi w pewnym stopniu je uzasadnić. Po trzecie, istnieją przekonania racjonalne, które powstają z wykorzystania ogólnej wrażliwości (emocjonalności) bez uzasadnienia. Po czwarte, można dysponować różnymi dowodami dla różnych twierdzeń: jeden dowód może wspierać jedno twierdzenie, a inny - inne (por. Audi 2002, s. 196).

Racjonalność globalna obejmuje nie tylko przekonania i pragnienia, ale także emocje, oceny, akty wolicjonalne i postawy (aprobaty i dezaprobaty). Te ostatnie - postawy wobec innych ludzi - są kompleksami przekonań, pragnień i emocji. Jeśli postawy te są właśnie tak ukonstytuowane, powinno być jasne, że ich racjonalność jest determinowana przez ich składowe, zwłaszcza przekonania i pragnienia. Ale dla spójnego i sprawnie działającego systemu poznawczego ważne są też emocje i akty wolicjonalne. Istotne są dopasowanie i spójność wszystkich tych elementów. Na te tematy Audi poczynił wiele interesujących spostrzeżeń i analiz, których nie sposób tutaj rekonstruować.

Racjonalność nie jest zarządzana przez jakieś reguły, które można by precyzyjnie zdefiniować i wyliczyć. Zdaniem Audiego da się jednak wskazać pewne ogólne zasady. Po pierwsze, istnieje ogólne dopasowanie przekonań i pragnień do doświadczenia. Po drugie, siła (strength) przekonań i pragnień (poziom oddziaływania) oraz konsolidacja (entrenchment) przekonań i pragnień (poziom oporu przed eliminacją) są istotne dla globalnej racjonalności: im silniejsze lub bardziej skonsolidowane są przekonania i pragnienia, tym większa jest ich istotność dla ogólnej racjonalności. Po trzecie, zakres (scope) - różnorodność istotnie odmiennych tematów, do których odnosi się przekonanie. Po czwarte, psychologiczna łączność (connectedness) - liczba innych nastawień propozycjonalnych i potencjalnych zachowań, na które może mieć wpływ dane przekonanie. Ważne są wreszcie, po piąte, dobre ugruntowanie (well-groundedness) i po szóste, responsywność względem racji (reasons-responsiveness) (por. Audi 2002, s. 208-209).

Dla racjonalności istotna jest też spójność. Poszukiwanie spójności często skutkuje zmianą przekonań lub modyfikacją pragnień. Ale jej brak nie prowadzi do całkowitej irracjonalności. Według Audiego niezbędne są pewnego rodzaju kompromisy: nie wszystko musi być uzasadnione, nie zawsze musimy dysponować spójnymi przekonaniami. Zarówno błędy w rozumowaniach, jak i pewne irracjonalne działania nie burzą ogólnej racjonalności osoby. Wyjaśnienie racjonalności teoretycznej i praktycznej daje nam też wiedzę potrzebną do zrozumienia tego, czym jest ogólna racjonalność osoby. Rezultatem tej wiedzy jest jednak i ta prawda: że niemożliwe są doskonała racjonalność teoretyczna, doskonała racjonalność praktyczna i pełna racjonalność ogólna. 


\section{Podsumowanie}

Istnieje wiele istotnych, wzajemnie powiązanych składowych w strukturze teorii racjonalności Audiego, które decydują o jej oryginalności i nowatorstwie. O niektórych z nich była mowa powyżej. Na koniec niech mi będzie wolno jedynie zwrócić uwagę na założenia, metodę pracy i cele, jakie stawia przed sobą amerykański filozof. Już to bowiem wystarczy do uchwycenia zasadniczej różnicy w podejściu Audiego i Kleszcza. Audi wychodzi od elementarnego doświadczenia zmysłowego i analizuje dynamikę procesu poznawczego. Eksploruje naturę racjonalności teoretycznej i praktycznej. Analizuje i syntezuje. Zestawia obok siebie obie racjonalności, wydobywa podobieństwa i różnice między nimi, a następnie sprawdza, na ile podobieństwa te mogą być zintegrowane i na ile dają zadowalające i pouczające ogólne wyjaśnienie racjonalności. A zatem nieco inaczej niż Kleszcz, który próbuje wyłowić i zbadać najważniejsze pojęcia racjonalności stosowane $\mathrm{w}$ różnych kontekstach, ale nade wszystko w dyskursie filozoficznym. To badanie pomaga mu - i nam - lepiej uchwycić relacje różnych pojęć racjonalności z innymi, powiązanymi z nim pojęciami i pojęciami przeciwstawnymi. Wydaje się, że Kleszcz jest dużo bardziej niż Audi sceptyczny wobec możliwości i potrzeby skonstruowania jednego, spójnego i nadrzędnego pojęcia racjonalności ${ }^{8}$. Zwłaszcza że takim pojęciem, tzn. pojęciem racjonalności uniwersalnej lub ogólnej, już dysponujemy. Pojęcie to Kleszcz wykorzystał w swojej autorskiej propozycji, w dwupiętrowym modelu racjonalności, jako punkt wyjścia. W modelu tym najpierw mamy do czynienia z poziomem podstawowym, który obejmuje ogólne zasady (niezbyt szczęśliwie określane przez Kleszcza „metazasadami"), a następnie z drugim poziomem, na którym odnaleźć można szczegółowe typy poznania i racjonalności.

\section{Bibliografia}

Audi R. (2001), The Architecture of Reason: The Structure and Substance of Rationality, Oxford University Press, Oxford.

Audi R. (2002), Sources of Knowledge. [w:] P.K. Moser (red.), The Oxford Handbook of Epistemology, Oxford University Press, Oxford.

Audi R. (2004), Reasons, Practical Reason, and Practical Reasoning, "Ratio (New Series)" 17, 2, s. 119-149.

${ }^{8}$ Jego zdaniem pojęcie racjonalności jest pojęciem rodzinnym w sensie Wittgensteina: „»Racjonalność« ma wiele użyć, nawet gdy ograniczyć się do sfery samej filozofii. Wydaje się, że termin tenże można traktować jako mający łzw. rodzinę znaczeń" (Kleszcz 2007a, s. 10). 
Audi R. (2004), Theoretical Rationality: Its Sources, Structure, and Scope, [w:] A.R. Mele, P. Rawling (red.), The Oxford Handbook of Rationality, Oxford University Press, Oxford, s. $17-44$.

Audi R. (2006), Practical Reasoning and Ethical Decision, Routledge, London-New York.

Audi R. (2010), Epistemology: A Contemporary Introduction to the Theory of Knowledge, wyd. 3, Routledge, London-New York.

Audi R. (2015), Rational Belief: Structure, Grounds, and Intellectual Virtue, Oxford University Press, Oxford.

Bronner G., Di Iorio F. (red.) (2018), The Mystery of Rationality: Mind, Beliefs and the Social Sciences, Springer, Cham.

Bunge M. (1987), Seven Desiderata For Rationality, Rationality: The Critical View, Nijhoff International Philosophy Series, 23, s. 5-15.

Kleszcz R. (1994), O rozumie, racjonalizmie i racjonalności, [w:] T. Buksiński (red.), Filozofia $w$ dobie przemian, Wydawnictwo Naukowe Instytutu Filozofii, Poznań, s. 347-361.

Kleszcz R. (1996a), Kryteria racjonalności, „Filozofia Nauki” 2, s. 121-133.

Kleszcz R. (1996b), Racjonalność logiczna, „Filozofia Nauki” 4, s. 39-49.

Kleszcz R. (1998), O racjonalności. Studium epistemologiczno-metodologiczne, Wydawnictwo Uniwersytetu Łódzkiego, Łódź.

Kleszcz R. (2001), O dwu rodzajach racjonalności działania, [w:] W.P. Glinkowski, A. Nowaczyk, J. Piórczyński (red.), Rozum w dziejach. Księga jubileuszowa Profesora Ryszarda Panasiuka, Wydawnictwo Uniwersytetu Łódzkiego, Łódź, s. 223-236.

Kleszcz R. (2003), O racjonalności i jej granicach, „Roczniki Filozoficzne” 1, s. 171-190.

Kleszcz R. (2007a), O racjonalności w filozofii, [w:] W. Kowalski, S. Wszołek (red.), Ponad demarkacja, Biblos, Tarnów, s. 7-24.

Kleszcz R. (2007b), O rozumie i wartościach, Wydawnictwo Wyższej Szkoły Humanistyczno-Ekonomicznej w Łodzi, Łódź.

Kleszcz R. (2008), Czy nauka jest racjonalna?, "Zagadnienia Naukoznawstwa" 3-4, s. 345354.

Schroeder T. (2004), Three Faces of Desire, Oxford University Press, New York.

Sinhababu N. (2017), Human Nature: How Desire Explains Action, Thought, and Feeling, Oxford University Press, Oxford.

Streszczenie: O racjonalności teoretycznej, praktycznej i globalnej w filozofii Roberta Audiego

Głównym celem artykułu jest przedstawienie filozofii racjonalności Roberta Audiego. Czynię to na tle analiz oraz podstawowych rozstrzygnięć zawartych w koncepcji racjonalności Ryszarda Kleszcza. Ten ostatni najpierw dokonuje krytycznego przeglądu najważniejszych pojęć racjonalności stosowanych w różnych kontekstach, a zwłaszcza w dyskursie filozoficznym, a następnie proponuje własne rozwiązanie: dwupiętrowy model racjonalności. Na pierwszym poziomie tego modelu znajdują się ogólne zasady („,metazasady”). Na drugim zaś bardziej szczegółowe typy racjonalności. A zatem inaczej niż Audi. Amerykański filozof wychodzi od elementarnego doświadczenia zmysłowego i bada dynamikę procesu poznawczego. Zestawia obok siebie dwie podstawowe racjonalności: 
teoretyczną i praktyczną. Omawia podstawowe źródła wiedzy i uzasadnienia, w tym uzasadnienie inferencyjne. Analizuje podstawowe źródła racjonalności praktycznej: pragnienia, motywy, intencje, środki i cele. Wydobywa podobieństwa i różnice między racjonalnością teoretyczną i praktyczna, a następnie sprawdza, na ile podobieństwa te mogą być zintegrowane i na ile dostarczają adekwatnego wyjaśnienia racjonalności globalnej.

Słowa kluczowe: teoria racjonalności, racjonalność teoretyczna, racjonalność praktyczna, dwupiętrowy model racjonalności, racjonalność globalna

Summary: On Theoretical, Practical and Global Rationality in Robert Audi's Philosophy

The main purpose of this paper is to present Robert Audi's philosophy of rationality. The task is performed against the background of analyzes and foundamental findings in Ryszard Kleszcz's conception of rationality. The Polish philosopher critically reviews the most significant concepts of rationality used in various contexts, especially in philosophical discourse, and proposes his own solution: a two-tier model of rationality. At one level of this model, there are general principles („,meta-principles"). At the other, more specific types of rationality. Hence, he differs from Audi. The American philosopher starts from elementary sensual experience and studies the dynamics of the cognitive process. He juxtaposes two basic rationalities: theoretical and practical. Audi discusses basic sources of knowledge and justifications, including inferential justification, and analyzes basic sources of practical rationality: desires, motives, intentions, means, and goals. He exposes similarities and differences between theoretical and practical rationality, and tests the extents to which these similarities can be integrated and provide an adequate explanation of global rationality.

Keywords: theory of rationality, theoretical rationality, practical rationality, two-tier model of rationality, global rationality 